\title{
The Search for Muslim Near-Death Experiences
}

\author{
Joel Ibrahim Kreps, M.D. \\ Montreal, Canada
}

\begin{abstract}
Given the dearth of Muslim near-death experiences (NDEs) in the literature, I decided to take advantage of my contacts in the Muslim community to find more of this material. After advertising unsuccessfully in both traditional media and Internet groups, I recruited a student resident of Pakistan who had considerable contacts and help there to visit the area of a major earthquake in the Kashmir area in the hope that this would be a fertile terrain to find additional NDE accounts. Once again the results were disappointing. I conclude that NDEs are specifically designed for people who need them, and the need in certain communities may not be as great because of the persistence of traditional faith in an afterlife and a Creator.
\end{abstract}

KEY WORDS: near-death experience; Islam.

More than 20 years ago, when I was just barely aware of the work of Raymond Moody (1975) delineating the characteristics of near-death experiences (NDEs), I was on a journey to Cairo, when I was invited to an Iftar dinner, the meal that breaks the fast during the holy month of Ramadan, at a Sufi friend's house. A middle-aged lady who was present began recounting a terrible traffic accident she had experienced in Kuwait 10 years earlier. As I was listening to her exposition, I remember thinking, "This is an almost classical NDE."

This woman recounted her head-on collision with an oncoming car, leaving her body just before impact, and being carried upwards into

Joel Ibrahim Kreps, M.D., is a psychiatrist in private practice in Montreal, Canada. A former teacher in the McGill University Faculty of Medicine, he has practiced Sufism (Islamic Mysticism) for more than 30 years, is a regular columnist for the magazine Islamica, and has maintained an enthusiastic interest in comparative religion. Reprint requests, inquiries, and comments should be addressed to Dr. Kreps at jebrahim2@ gmail.com. 
the heavenly realms. Then she witnessed the arsh (throne) of God and saw the Muslim testimony of faith written above the throne: Laillahah illalah, Muhamadan Rasussululah (There is no God but God, and Muhammad is His messenger). That is all I remember of her account, and I have been unable to locate her ever since. However, I was left with the distinct impression that NDE accounts in the Muslim world would be as legion as they are in the Christian world and that they would be easy to locate.

This impression has turned out definitely not to be the case. Following the prolific NDE literature trail over the years, one cannot help but notice the preponderance of accounts emerging from the Christian world. Even in the studies done on Hindu and Buddhist NDEs, such as by Karlis Osis and Erlendur Haraldsson (1977), Satwant Pasricha (1993), and Todd Murphy (2001), the accounts tend to be brief and sketchy, lacking the depth of Christian accounts such as those of Betty Eadie (Eadie \& Taylor, 1992), George Ritchie (1991), and Dannion Brinkley (Brinkley \& Perry, 1994). The net result has been numerous and lengthy accounts of meetings with Jesus, some fleeting references to Hindu deities and to the Buddha, and almost nothing connected specifically to the Islamic tradition or many other traditions. For example, I am unaware of any accounts of NDEs involving Guru Nanak of the Sikh tradition or Lao Tzu or Confucius of the Chinese traditions.

With all of these observations in mind, I began searching for Muslim NDEs, expecting to see many accounts of Muslims meeting with the Prophet Muhammad in the afterlife. This expectation was even stronger given that there are numerous accounts of Muslim saints known as awliya (friends of Allah) meeting Muhammad either in dreams or in daytime visions. Two of the more notable saints involved in these kind of meetings were Abu Hassan ash-Shadhili, originator of the great Sufi tariqat, the Shadhili Order, and Ibn al-Arabi, the great Andalusian Sufi also known as the Sheikh al-Akbar, or the greatest Sheikh. I will describe his account, which is very similar to an actual NDE, later in order to highlight the specificity of the Islamic perspective on Ultimate Reality.

\section{Preliminary Searches}

My first attempt to research this subject involved searching the Internet. The pickings were meager indeed. Despite considerable 
information available on the Muslim theory of the afterlife, of which almost all Muslim scholars and many pious Muslims are well aware, I found few actual reports of Muslim NDEs. The only real report that came up was entitled "Mebruke's Near-Death Experience" (Morse \& Perry, 1994), which recounted a near-drowning experience of a 20year-old Saudi Arabian woman in the Mediterranean Sea off the coast of Italy. This report was a somewhat typical NDE: a drowning, seeing the "beautiful white light," being told it was not her time to die, and being propelled out of the water. Although reassuring in a certain sense to see that Muslims do have NDEs similar to others' NDEs, it provided no particular Muslim dimensions nor did it help to separate this specific religious point of view from others.

After several more futile attempts on the Internet, including searching through some of the more elaborate websites such as Jody Long and Jeffrey Long's NDE Research Foundation (www.nderf.org) for names such as Ahmad, Mahmud, and Fatima, I went through the titles of the Journal of Near-Death Studies. Finally I contacted the International Association for Near-Death Studies (IANDS) and spoke to its then-secretary Diane Corcoran, who put me in touch with the book of Azmina Suleman.

\section{A Passage to Eternity (2004)}

Suleman presented a fascinating, in-depth account of an NDE following a bout of acute necrotizing pancreatitis while on vacation in Florida. She described in great detail her experience of a "multidimensional place of layered existences." Many things can be learned from her account, but I would like to focus on what occurred in the "sixth dimension" as she was getting close to the "Absolute Reality of Divine Light." She began:

Then, from within that solitary ray of brilliance, I saw several of God's Messengers manifest themselves and stand before me in all their shining glory.

As I watched in stunned silence, I realized that I was once again witnessing a "powered down" version of these illuminated beings of light. Yet, this august body of individuals before me seemed somewhat more radiant, more vibrant, and more translucent than the individuals in my previous group [who included Mahatma Gandhi and Martin Luther King, Jr]....

The individuals within this present group seemed totally immersed and enshrouded in light. They seemed to be projecting themselves out of a single ray of light as opposed to a series of separate and distinct 
lights, suggesting a lesser degree of separation from that one light source, God. Even though I could feel the glowing presence of several radiant beings of light within that Light, I seemed to be able to identify only seven. (Suleman, 2004, p. 60)

Suleman (2004) then began to identify the different messengers. She started with the "lone and bearded" (p. 61) prophet Noah and then continued with the pairs of the prophet Moses with Jesus, a crosslegged Buddha next to Lord Krishna, and finally the prophet Muhammad with Hazrat Ali, his son-in-law and successor. In a somewhat surprising association, both to Suleman herself (p. 61) and from the point of view of Muslim and Christian theologians, next to the prophet Muhammad was the Virgin Mary.

Coming out of the luminous form of the prophet Muhammad was the luminous face of Ali, whom Suleman referred to as "my Beloved Lord" (p. 62). This association would be of no surprise to Sufis because Ali, the son-in-law and cousin of the Prophet, is considered the head and source of 40 of the 41 tariqats, or orders of Sufism. Nor would it be surprising to Muslim scholars, for a well-known hadith (tradition) of the Prophet, peace and blessings be upon him, states: "I am the city of knowledge and Ali is the door to that city." Furthermore, in Shia Islam, Ali is a very central figure, being the only authentic successor of the Prophet Muhammad and the first imam.

Many non-Muslims reading Suleman's account have concluded that it is a substantial account of a Muslim NDE. However, there are a number of qualifications to consider before arriving at this conclusion. Suleman came from the Ismaili sect of Islam, which is actually a breakaway sect of Shia Islam with its own set of beliefs and practices. Most traditional Muslims, both Sunni and Shia, would consider them outside of the Islamic framework and would object to them being described as Muslims.

The Ismaili are known as "Seveners" because they believe that Jaffar, the seventh Shia imam, was the last imam. In this way they differ from the majority of Shiites, who are considered "Twelvers" because they believe in twelve imams, of which the twelfth is the hidden Messiah.

Furthermore, the Ismaili credo is considered by many scholars to be a form of Gnosticism. Ismailis' beliefs are complex and syncretic and include elements from the philosophies of Plotinus, Aristotle, and the Manicheans, as well as components of Judaism, Christianity, and Eastern religions. More specifically, the Khoja Ismaili beliefs, from the 
followers of Aga Khan, represent a unique synthesis of Hindu and Islamic doctrines and tenets. All of this theology would be considered heterodox or heretical by mainstream Muslim groups.

I am describing these beliefs in order to situate Suleman's NDE within the context of her own community's belief system. It is not surprising, then, for a follower of Sevener Shiism to see a collection of seven prophets being found together. Nor is it unusual to find deities and representatives from the Hindu and Buddhist traditions. From everything I know about NDEs and the Islamic tradition, however, I believe it would be highly unlikely that Sunni Muslims would have Hindu deities involved in their NDEs. If this occurred, they would most likely be as concerned as would be believing Christians that they had fallen into the realms of illusion or even of demonic influence.

Despite these important theological differences between Ismaili Islam and mainstream Islam, it is nevertheless satisfying and reassuring to hear of NDEs that include the prophet Muhammad and one of his major successors, Hazrat Ali. From a Muslim perspective, this inclusion increases the credibility of these otherworldly experiences. For this aspect alone, I consider Suleman's writing to be an important contribution.

\section{Urdu Near-Death Literature}

As I was researching the literature for Muslim NDEs, I heard reports of Urdu accounts. In fact, one of the major Islamic scholars of our time, Taqi Usmani of Da-rul-Uloom in Pakistan, has written a chapter entitled Zikro-Fikr [Meditation and Contemplation] in his book Dunya Ke Us Par [This World and the Beyond] on the NDE (Usmani, 2009). In this chapter he recounted some Christian NDEs, such as that of George Ritchie, and summarized Moody's work for the Urdu-speaking and Muslim worlds. However, he included no new Muslim NDEs in his book.

On the other hand, a doctor, Amjad Ali Jaffri, contributed two reports in the June 2001 issue of the Urdu magazine Al Balagh. These reports contained some interesting nuances to the classical NDE accounts, and they have been translated for me by Hassan Mian, a fellow Sufi practitioner and Muslim theology student.

The first report came from August 1955 when Jaffri was participating in an Alpine club expedition at a place called Dara Ratti Galli, not far from Belokot, the site of the recent earthquake in Pakistan, at an 
altitude of 17,000 feet. A landside occurred and Jaffri was buried under tons of earth:

I felt my being escaping, coming out of my body from everywhere. Around me were several beings of light and I was familiar with none of them. Knowing about the events of the life of the Prophet Muhammad, I believed it was either him or Ali ibn Talib or someone else who resembles them. These individuals were communicating with me through telepathy. They were telling me not to worry, and to be calm. They gave me other messages, which we will describe later. I went into a state of total peace. (Jaffri, 2001).

He went on to describe something we have come to know as the out-ofbody experience (OBE):

My spiritual existence (soul) was witnessing the chaos from the other side of the mountain. I remember the names of the individuals in the rescue party who were worried about me. An officer of the Azad Kashmir Group was trying to convince the supervisor of the rescue operation to dig at a different place. The people were convinced by this engineer's arguments and started digging at the new place, which is where my body was eventually recovered. When I recounted all that had occurred to the rescue team they were astonished. I told them in great detail what each of them had said, including those that had said "forget about him" and wanted to abandon the search. Despite all of this, they still did not believe me. (Jaffri, 2001)

All of this is very reminiscent of the people in the surgical theater or in various stages of coma with flat electrocardiograms in Western hospitals telling the treatment team exactly what they were saying during the resuscitation procedures. It is one of the forms of evidence most difficult for skeptics and doubters to deny. It seems that the Pakistani Muslims in this account shared the same skepticism as do Westerners.

The second incident Jaffri recounted involved a serious heart attack in March 1984. He was in the hospital at the time:

My nails and lips became blue, my blood stopped circulating, and my neck lost support leading to my head falling to one side. My wife yelled out of fear, and the doctors raced towards me to provide emergency treatment. Medicine was injected into my chest, and they tried to make my heart work by pressing my body [standard cardiopulmonary resuscitation (CPR) treatment]. They then administered electric shocks to make my heart start up [defibrillation]. The doctors finally gave up and covered my face. As a senior doctor came over to my wife and was searching for words to tell her of my demise, a younger doctor appeared from the other room to say he had seen some movement in my body. I was getting some life back after not 
having a heart beat for over 20 minutes! (Jaffri, 2001, bracketed material added)

All of this material sounds quite familiar to people who know about NDEs. Then the spiritual experience came:

I saw a person of light coming towards me before I left my body. As soon as he touched me I felt my soul leaving the body. It started in my feet and moved towards my head. Finally, I became a small being of light myself. While in the company of this other being of light I was very relaxed.

I was now near my body with this man of light when suddenly a tunnel of light formed on my right side. I enjoyed the beautiful scenes in this tunnel. I also saw waves of energy leaving the hospital and was told by the being of light that these were the prayers of people praying for me rising up. (Jaffri, 2001)

The notion of prayers rising up as waves of energy is an interesting touch here. It speaks to the reality of prayers from the Muslim perspective.

Then I was told by telepathy that I had to go back. This was repeated since I didn't want to go, but the return was inevitable. Finally, someone pushed me from behind, and I entered my body. I felt the weight that I had been carrying for a long time, and had to do so again. (Jaffri, 2001)

Then came an interesting twist. Jaffri explained:

During both these experiences I received the following teachings:

1) Show good behavior to all creation.

2) Love all creation.

3) Don't hurt anyone.

4) Give people their rights.

5) Don't forget the rights of Allah (God).

6) Do every deed in a good way, with the right intention, and for the pleasure of God.

7) When doing something for the first time, if you feel it is wrong, leave it, and don't do it again.

8) Eat hallal (permissible) provisions and earn your money in a hallal (permissible and ethical) way and be strict about honesty.

9) Man has no control over many things in his life such as his skin color, his language, his feelings, and his temperament. These are from the will of God. 
10) Whenever a person is in doubt about his actions, he should consult with a knowledgeable person and correct himself. (Jaffri, 2001)

We can see in these 10 principles the common moral inheritance of humankind. Much of this guidance is contained in the various spiritual and religious teaching known to humankind. However, a few concepts from this list are more typical of Islamic consciousness: for example, the importance of food and earnings that are hallal, or legally permissible according to Islamic Shariah. Additionally, the importance of consultation, as in principle number 10, is a strong Islamic concept; the Prophet Muhammad had emphasized it on numerous occasions. The first three principles, about loving and protecting all of creation, sound almost Christian or Buddhist in tone.

Perhaps the most specific Islamic idea here has to do with the "rights of God" and doing everything for the "good pleasure of God." This principle is especially interesting because some near-death experiencers (NDErs) give a more secular humanist "spin" to their accounts. They often note, for example, that in the "life review" they are shown their good and bad deeds relative to human beings, but the issue of prayers and specific religious practices is rarely mentioned.

In Jaffri's (2001) account, however, the rights of God take on special importance. NDEs surely reflect the state of consciousness and the state of evolution of the experiencers. If they have not received training and instruction about their relationship to God, this material may not appear in their NDEs. It appears as though NDEs are specifically prescribed to the NDEr's needs and level of spiritual development. It is as if the purpose of the experience is to bring the experiencer to the next level.

Another interesting aspect of this particular experience is its universality. As one can observe on the contemporary world stage, Muslims have become, in many instances, overly sectarian. This was not always the case, but at this point in time it has caused enormous damage and suffering. Muslim NDEs, however, are much more universal and caring in character, reflecting earlier and better times in Islamic history.

\section{The Pakistani Earthquake Research Project}

Given the dearth of reported NDEs amongst Muslims, I decided it was incumbent on me to do more research. My first attempt involved 
the Internet, once again. I signed up for several popular Muslim lists and groups and put out the message that I was looking for Muslim NDEs. I received many responses referring to relevant Muslim beliefs and theology, but none to actual raw experiences. The only serious responses I received referred me back to the previously mentioned Urdu article in Al Balagh. Some of these web lists had thousands of members enrolled, but I received no positive responses. Then I put advertisements in several Asian and Muslim magazines with circulations of more than 100,000 readers, but still received no response.

I was becoming somewhat despondent when, on hearing about the article on the Chinese earthquake (Zhi-ying \& Jian-Xun, 1992), a friend suggested that I look into the recent earthquake in the Pakistani Kashmir area. Given the fact that 32 out of 81 survivors interviewed (40\%) after the Chinese earthquake had NDEs, this Pakistani target population seemed particularly promising.

We then began the search for a research assistant who could do the fieldwork in the area and came up with a bright and diligent university student named Haroon Agha who was in Pakistan for the summer and free to do some traveling. He also spoke Urdu fluently, had connections in Islamabad with one of the trauma centers doing earthquake relief, and was interested in the project. He agreed to participate. In quick order we set up the parameters of the study, determined the questions to be asked, and negotiated a small but adequate budget.

I was particularly interested in questions related to the specificity of the Islamic revelation. I wanted to know if people experienced the life review and what they were held accountable for. I also, of course, wanted to know if they reported meetings with any of the important Islamic figures, such as the Prophet Muhammad or his sahabas or companions, somewhat like the apostles of Jesus; or the Islamic saints known as awliya; or the Angel Gabriel or other angels. Given the high yield after the Chinese earthquake, I approached this search with eager anticipation.

Haroon, our research assistant, was known by the people who had studied with him to be a thorough and diligent student, and I had full confidence that if something was to be discovered, he would find it. I did not want to lock him into a grid of preconceived questions such as those used by Osis and Haraldsson in their studies, nor the schema of the Longs' Near-Death Experiences Research Foundation questionnaire (www.nderf.org). Because I myself have found the more lengthy 
accounts such as those of Eadie and Suleman much more edifying, I chose to avoid the route of standardized questionnaires, quantification, and statistical analysis.

For a period of six weeks, Haroon and I e-mailed back and forth from Montreal to places like Islamabad, Muzaffarabad, and Lahore. Haroon attempted to share with me his observations, and I attempted to guide him as best I could on a difficult journey.

The first reports from Muzaffarabad were of a city in total devastation: All that remained of the inner city was debris. Many of the surrounding villages had disappeared from the landscape. The villagers were obliged to camp in tents, perilously close to the danger lines, and summer monsoons had claimed fresh victims from the landslides. Bodies from the earthquake were still being discovered on a daily basis.

Haroon and his group traveled to the villages that were most affected. People who had lost everything were camped on the mountainside in tents. Gathered in a narrow strip of remaining land, coming from numerous villages that had all been obliterated, the locals would point to where their villages had been and were no more. The devastation was mind-boggling. Nearly everyone they talked to had lost loved ones, but none of them had come across or heard of an NDE-like experience.

We were told that people would be reluctant to engage with strangers and were still concerned about the lack of help from their own government. Thus, in order to take advantage of his familiarity with the people of the area, we recruited a local teacher, Muhammad Shafeeq, who spoke the local idiomatic language, and we explained to him the nature of the mission. Shafeeq, as well as the guide for their travels and numerous other government officials, were unable to come up with a single NDE, despite numerous efforts to inquire amongst the local population. In response to any questions, the locals would just recount over and over again the trauma that had occurred.

An interesting note is many accounts of miraculous events other than NDEs amongst the survivors. The most frequent of these were stories of bodies being recovered months after the event, but still intact and undecayed. Even as our researchers were looking for NDEs, bodies were still being recovered intact and uncorrupted. This is a phenomenon reported often in the Muslim world and is seen as a sign of wilayat or sainthood. The nature of our brief research project was not such that we could document and record these occurrences, but the reports were frequent and repetitive enough to suggest their credibility. 
In Muzaffarabad, one of the areas most affected, the research team worked from the auditor general's office of the survivors' camp. Nearly all of the staff there had lost close family members. A guide from the office went up to the villages where the destruction was worst, about 2,000 feet up from Muzzafarabad. From these villages commuters regularly went to town in the morning to work and came back in the evening. The guide in question took the researchers up to his family and to the other villagers.

Many villagers gathered round them, and their stories were legion, but mostly they all had the same tone:

I was thrown upwards and fell hard to the ground. The ground underneath went up and down. Then it rotated so I could not maintain my balance. There were deep roars from the mountainside. Everything shook violently. Lying on the ground, I could not even crawl out of my house. I couldn't figure out what was going on; it was like the end of the world - the Day of Judgment.

After repeated attempts to elicit NDE accounts from these affected villagers, Haroon decided on another tactic: addressing inquiries to the professionals and institutions involved in relief efforts and treatment facilities.

One of the first he contacted was Waqar Haider, a cardiologist from the affected center and an employee of the Combined Military Hospital. Haider was one of the few doctors who had survived the earthquake. After a university building near his house was completely destroyed, he had recovered the bodies of 90 science students in the midst of taking exams. Despite his own personal catastrophes, he gave full support to the mission and called back those patients whom he thought might be open to NDEs. They all confirmed remembering nothing.

Haider had resuscitated five or six patients himself after the earthquake. When interviewed, none of them reported anything like an NDE. Previously, Haider had been interested in the work of Moody, and had been involved himself in more than 4,000 cardiac and other surgeries but had been unable to elicit any NDEs. Frustrated by his efforts, he had become skeptical of the existence of this phenomenon.

In addition, one of the numerous research expeditions went to the Punjab Cardiac Center, a major treatment center for cardiac disease in Pakistan. There the emergency staff and doctors were intensively interviewed to try to gather NDEs, but once again the interviewers came up empty-handed. 
In Islamabad, after the earthquakes, medical personnel set up various trauma centers for post-operative care and for people recovering from shock. At one of these centers, the Bali foundation, two volunteers who had heard the intimate stories of nearly 200 people maintained that the people were very open in recounting the personal details of their stories. Among these people were paraplegics and people with serious back surgeries and amputations. In all of these cases, not one NDE account came up.

Finally, based on the study of paraplegics from the Chinese earthquakes at the rehabilitation center, we conducted systematic interviews of 45 patients at the Islamic Center for the Handicapped in Islamabad. We approached these patients gently at first, listening to their stories, and then after we sensed we had achieved a certain comfort level, we asked more direct questions. Of these 45 patients only two claimed they had "seen light," and none of their accounts would qualify for even a partial NDE.

Why were there almost no accounts of NDEs in the Pakistani earthquake experience? The results were certainly not what we expected initially. Haider thought the problem might be the inefficient Pakistani CPR methods that were ineffective relative to what is done in Western hospitals. I personally did not consider this an adequate explanation, as we have many accounts in the West of NDEs in perilous situations, such as accidents, other illness, and lightning strikes, unrelated to cardiac resuscitation.

My initial theory was that people would be too embarrassed to tell their story or would be afraid that this went against their religious beliefs. I had instructed the researchers to tell people that a very important Islamic scholar, Taqi Uthmani, has written about these experiences in a positive light and that there was nothing in NDEs that went against Islamic beliefs. However, my theory did not add up either. The interviewers were generally convinced that the people being interviewed were open and spontaneous. There was no evidence of concealment or repression in their interactions.

\section{Three Incidental NDE Accounts}

My research collaborators did record three experiences, even though they were unrelated to the earthquake. Instead, my collaborators found them through their own personal contacts. 
The first account was from Fehmida Hassan of Karachi, an elderly lady who had had her experience 10 years previously. She had been pronounced dead at the hospital. The doctors nevertheless performed CPR, which was successful. While unconscious, she tried to move her right hand to write something, but it wouldn't work, so she was given a pen and paper and wrote with her left hand, "Ask people to forgive me." When she recovered, she had no recollection of this action. The nature of her symptoms, however, would suggest that she had suffered a serious stroke.

During her period of unconsciousness she had experienced herself flying. The feeling was wonderful, but she was puzzled at how she could fly without wings. She asked where she was going. A voice answered her and directed her to approach the bright light ahead. She began flying towards it but was stopped midway to the light and turned around.

During her OBE, she began a conversation with her next-door neighbor and told her to make funeral arrangements for the young boy in the next bed in the intensive care unit. In fact, while this experiencer had been unconscious, a young boy did die of cardiac arrest at that place and time.

She woke up to realize that she could breathe on her own. The ventilator had been removed. Happy and smiling, as she awoke she was reciting an Islamic prayer called the kalima. She felt no pain except in the vocal cords, most likely from the endotrachial tube, from which she recovered over the next few months.

The second account was from Masuma, a woman who had had major surgery with splenectomy. Post-operatively she developed a massive infection and hemorrhage and was unconscious for 10 days. The following experiences occurred during her hospital stay in London.

She saw an intense light ahead of her, sparkling and white as from a kaleidoscope. She experienced herself flying through space on a long journey where she met various people, including "men dressed in white robes" who restrained her and implored her to help certain people on Earth, but then released her saying they would take care of the matter themselves.

During her experience, she saw the wedding of a friend's daughter who, in material reality, was unmarried. She felt that there was a good possibility that this was a precognitive experience. Because she saw clearly the face of the bridegroom, she was hoping to confirm in the future the accuracy of her vision. She also saw a particular relative 
who was visiting her while she was unconscious. This relative had, in fact, come to the hospital while she was in a coma.

When she came to, it took her a long time to realize that her visions were not the reality of this world. She felt that her real life was in the journey to the light where she had been very happy and had no worries.

The third account came from Aisha Mohsin, a woman who had had a serious allergic reaction to an antimalarial injection 30 years previously. She was taken to the hospital unconscious.

She remembered being in a treatment room levitating above her inert body. She could see and hear all the doctors and staff around the body talking to each other. At the time she felt very peaceful. She remembered hearing the doctors asking her to move her finger, but she was unable to do so. She realized by the worried expression on their faces that she could be dying, so she too began reciting the kalima, the Islamic testimony of faith. During the entire experience she felt happy and positive and had lost all sense of time.

We can see by these brief accounts that Muslim NDEs have many of the same characteristics as NDEs of people from other faiths. More specifically, we notice (1) the extracorporeal aspect, levitating over the body and flying through the air as if on a journey; (2) the intense light that people move towards; (3) the feeling of peace and happiness; (4) the clairvoyant or precognitive aspects such as seeing a future bridegroom and having awareness of an imminent death of another being as in the case of Hassan and the young boy in the intensive care unit; and (5) the meeting with beings dressed in white acting as guides to the light.

In brief, there are many similarities in these experiences with Western NDEs but some differences. For example, I have not come across any Muslims who have undergone a life review. Nor, of course, did any of them meet with Jesus. On the other hand, very few have met with the Prophet Muhammad, either.

\section{The Experience of Ibn al-Arabi}

The one NDE-like experience best known to Muslims is that of the Prophet Muhammad during his Isra (Night Journey) and Miraj (Ascension). This event was a turning point in the prophetic mission. During this journey, within a short space of time, the Prophet reported that he had gone to Jerusalem; ascended to the various levels of heaven; met with many of the major prophets of previous revelations, including Abraham, Jesus, and Moses; and been taken to the presence 
of God in the World of Unity. He was also at this time given the order for the Muslim Salat, the definitive prayer of the Muslim community, and instructed to teach it to his people.

Many in the Meccan community of his time used this story as a means to mock the Prophet and described his story as preposterous. However, the true followers of Islam and most notably Abu Bakr Siddiq, the Veracious One, accepted this experience as a miraculous event and another sign from God of the authenticity of the message.

Because this event is so integral to the Islamic message and because many Islamic scholars believe it took place in the body rather than being a journey of the soul outside the body, I do not regard it as an NDE but rather consider it as a miraculous event outside of the purview of our study of more ordinary NDEs.

In contrast, we will look at the experience of one of the great Islamic saints, Muhyiddin Ibn al-Arabi, also known as Sheikh Al Akbar, the greatest Sheikh. Ibn al-Arabi, originally from Andalusia, was one of the great spiritual seekers and mystics of the Islamic tradition. After a lifetime of studying, traveling, and spiritual practices and asceticism, he arrived at Mecca, the "Mother of Cities" and the destination of all Islamic pilgrims. There he wrote what is arguably his greatest work, Futuhat Al Makkiya [The Meccan Revelations] (Ibn al-Arabi, 1202/ $2002,1202 / 2004)$. In it, he gave the account of his appointment to the station of the Seal of Universal Sainthood, the saintly equivalent of the Seal of Prophethood that belongs to the prophet Muhammad in Islamic teachings. Ibn al-Arabi recounted:

I saw him [the Prophet] in this [Imaginal] World, sovereign, quite unapproachable, protected from every gaze or glance, aided and assisted. The Messengers stood by him according to their rank; his community - which is the best of communities [Qur'an 3:106] surrounded him; the Angels of Dominion stood around the throne of his Station and the Angels engendered by [people's] actions were ranged in front of him. The Veracious One [i.e., Abu Bakr (Abu Bakr Siddiq, the first successor of the prophet)] was seated on his sublime right; the Discriminator [Umar (Umar al Khattab, the second successor)] on his holy left; the Seal [Jesus (a prophet of God in Islamic tradition)] was squatting in front of him and speaking to him about the history of Woman; at the same time, Ali (the fourth successor and father of most Sufi tariqats [orders]) ... was interpreting in his own language the words spoken by the Seal, and the Possessor of the two lights [Uthman (the third successor and husband of two of the prophet's daughters)], wearing the cloak of modesty, stood in front as is his custom. He [the Prophet (Muhammad)] saw me behind the Seal [i.e., Jesus] - I was standing there because of the 
similarity between his status and mine - and said to him: "This man is your equal, your son and your friend; draw up for him in front of me the seat of tamarisk". He then gestured to me and said: "Rise up Muhammad (another name for Ibn al-Arabi), take your place on this seat and sing the praises of He who sent me [God] - and mine as well (the Islamic tradition of salawat - praising the Prophet) because in you there is a portion of me which can no longer tolerate being far from me: it is that portion which governs your innermost reality".... Then the Seal drew up the seat on that solemn spot. On the top of it the following words were inscribed in blue light: "This is the purest of Muhammadan stations! He who seats himself upon it is his Heir; he has been sent by God to preserve the Sacred Law!" In that moment I was granted the Gifts of Wisdoms; and it was as if the Totalities of Words (jawami al-kalim) had been bestowed upon me. (According to the Qur'an, this was the legacy bestowed upon Adam as the first human.) Finally, from this sublime vision I was sent back to the lower world .... (Addas, 1993, p. 199; bracketed and parenthetical material added)

A number of points can be raised relative to the nature of this experience. Because the exact precipitating circumstances of this experience are not known, it cannot be known whether it constituted a proper NDE. Some authors in the field of near-death studies, however, believe NDEs are mystical experiences in essence; these authors include Carol Zaleski (1985) and Yvonne Kason (2008). Are then mystical experiences not NDEs as well? That is a matter for reflection.

Another very interesting aspect of this experience is how it reflected the beliefs of Sunni Islam. These beliefs include the primacy of the role of Muhammad and the importance of the Khalifat Rashideen: the Rightly-guided Successors Abu-Bakr, Omar Ibn al-Khattab, Uthmann, and Ali. Jesus was given a very important function, but neither that of son of God nor of God incarnate. Furthermore, sainthood, such as that of Ibn al-Arabi, was distinguished from prophethood, such as that of prophet Muhammad. This account was in contradistinction to the very interesting NDE of Suleman cited above, which represented the worldview of Ismailis.

Another issue raised by the Ibn al-Arabi experience was how an NDE may be affected by the piety and spiritual practices of the experiencer. There is a lot of discussion in the literature of NDEs about religious beliefs but little about the intensity of the actual religious or spiritual practice of the experiencers. There are, in fact, precious few NDE accounts of people who have been involved in intense spiritual practice or those seriously following spiritual teachers, sheikhs, or gurus of the various traditions. 
The experience of Ibn $\mathrm{Al}$ Arabi raised one more question related to the issue of methodology. Sufism teaches that the way of spiritual ascent involves Fana, or annihilation of one's being. This annihilation occurs through three successive stages: (1) Fana fi Sheikh, or annihilation in the sheikh; (2) Fana fi Rasul, or annihilation in the messenger; and (3) Fana fi Allah, or annihilation or unification with God or Godconsciousness. This progression raises the question of who we humans really are and how this sense of identity may change as we ascend on the spiritual path. Our identity is linked to our consciousness. If, then, we are united with the consciousness of God, are we then God? Most Muslims would consider this blasphemy or heresy, and in fact Sufis have been executed for making such claims. For all practical purposes, our identities are separate and distinct. Even if we can experience our unity with the Divine Light, it is better to think of ourselves as His creation or His servant, in order to accomplish our earthly mission.

\section{A Patient in My Office}

As often happens, after searching far afield, one comes up with answers closer to home. In this case it concerned one of the patients in my own practice, a young woman of North African descent who had had a very difficult life, including sickness, an abusive husband, distant and unempathic parents, and sickness in her own children. In her youth, she had had numerous visions of other worlds and clairvoyant capacities in which she was able to see future events occurring. She also had had dreams and visions of deceased family members, including saintly ancestors giving her guidance and support.

At the time of the experience I recount here, she was 21 years old and in the midst of falling asleep:

My feet were suddenly paralyzed and cold as if death were coming. Then I became a pure, white, transparent spirit, ascending towards heaven. All around me were other intense white lights. The lights seemed to serve as a barrier between me and God. I was accompanied by a luminous angel at my side. There was strong light everywhere around me as well as light coming from behind God.

Then God said to me, "It's time for your death. Give me one good reason why you should remain alive."

The woman then answered, "I will do good in the world." And God answered her, "I will give you another chance." And she returned suddenly to her body. 
During this same experience she could see all of history as it occurred and was about to occur, and the events of World War III unfolding in front of her. One aspect of this intriguing experience stood out to me. Whereas many NDErs report wanting to stay in the other world but are forced to come back, in this case the woman herself wanted to return in order to do good. At the time she did not know exactly what form this good work would take. Many years later when she had children, she realized it took the form of raising them.

We can note as well the importance of light and beings of light, something common to many NDEs. However, here we see light being perceived as a veil, blocking the vision of the ineffable and formless God. Light as a veil before the Divine Reality is a concept familiar to Islamic mystics.

\section{Conclusions}

Despite the recounting of several Muslim NDEs in this article, they appear to be quite rare in fact. All the research in Pakistan in the earthquake zone, at the cardiac centers, in the rehabilitation centers presumably fertile zones for finding NDEs - turned up not a single one. This result stands out in stark contrast to the $40 \%$ yield at the Chinese rehabilitation center and the average incidence of $35 \%$ in retrospective studies and $17 \%$ in prospective studies (Zingrone \& Alvarado, 2009). That difference requires some explanation.

One of the last questions I asked the researchers to look into was how the religious faith of the earthquake victims stood up to the test of this catastrophe. In response I received the following summary:

Nearly everyone we talked to was impacted positively by the earthquake, in terms of their faith. They are Muslims who are simple in spirit, not always very knowledgeable, even about their own religion, but very humble and God-fearing. They remember God often [a practice known as Dhikr in Islam]. None of them complained about their tragedies which often involved loss of many family members close to them. Although initially in shock, now they look back and hope that those who passed away had died as martyrs and were forgiven their sins. "We have seen the Day of Judgment," some said, "and now we have no excuse but to believe with complete certainty."

This reaction may seem surprising to people raised in the secular West, and some readers may even accuse my research collaborators and myself of romanticizing. However, it is not that long ago that 
many people in the West would have had a similar reaction. This particular context, that of the earthquake victims, led me to a different hypothesis as to what may have occurred.

Several possibilities exist as to this dearth of actual NDEs. I have already addressed the idea proposed originally by Haider that the CPR methods of Pakistani doctors and rescue teams were less effective than those of their Western counterparts, which I believe lacks credibility.

Another possibility was that the events were too recent, and thus the people involved were still suffering from the effects of shock. By contrast, the Chinese earthquake victims were interviewed more than 20 years after the events and so had time to recover and gain some objectivity. However, there are many reports in the NDE literature of people telling their stories almost immediately upon coming back to consciousness, such as after CPR, so that this explanation as well lacks credibility.

A third possibility was that the victims were too ashamed of what they had experienced and were afraid that people would consider them crazy or, even worse in their society, as heretics outside the accepted beliefs of Islam. There were stories I have come across over the years of Muslims who were reluctant to tell their stories or who asked for confidentiality before speaking. However, in general, this was not the impression of the interviewers on this particular project. Instead, they felt that the majority of the victims were open and trusting and recounted exactly what they remembered.

So what are we left with as an explanation? A hypothesis that came to me after long reflection is based on the view of life as essentially a learning experience. This is a consistent conclusion from the NDE literature: We are here to gain knowledge and to learn about love (Ring \& Valarino, 1998). The NDE is thus also a teaching, one specifically prescribed for each NDEr. Because we are living in an age in which people have grown distant from their religious and spiritual foundations, God - or the Universal Consciousness or Nature, if the reader prefers - has sent NDEs to remind us humans why we are here and what our ultimate destination is. Several NDEs, such as those of Ritchie (1991) and Eadie (Eadie \& Taylor, 1992), contained the specific message to inform people about the existence of God and his delegate Jesus.

These Pakistani Muslims, however, did not need this type of message. They were already believers in their own revelation, the Qur'an, and the tragic events around them served only to confirm their faith. They were given their own reminders and their own tests. But ultimately, each specific event in our lives, including an NDE, is a 
specific prescription for us as individuals. Those who have NDEs are those who need them. In other cases, it is the people around them who are in need of this witnessing.

This explanation may not be acceptable to everyone, especially to skeptics, but it is the most satisfying one that I have been able to come up with. I hope, as well, that this explanation can be helpful to the readers of this article.

\section{References}

Addas, C. (1993). Quest for the red sulphur: The life of Ibn Arabi. Cambridge, England: Islamic Texts Society. Retrieved from http:/www.amazon.com/Quest-Red-SulphurIslamic-Society/dp/0946621454\#reader_0946621454

Brinkley, D., \& Perry, P. (1994). Saved by the light. New York, NY: Random House.

Eadie, B., \& Taylor, C. (1992). Embraced by the light. Placerville, CA: Gold Leaf Press. Ibn al-Arabi, M. (2002). The Meccan revelations, Volume I. (W. C. Chittick \& J. W. Morris, Trans.; M. Chodkiewicz [Ed.]) New York, NY: Pir Press. (Original work published in 1202 in Arabic)

Ibn al-Arabi, M. (2004). The Meccan revelations, Volume II. (C. Chodkiewicz, D. Gril, \& D. Straight, Trans.; M. Chodkiewicz [Ed.]) New York, NY: Pir Press. (Original work published in 1202 in Arabic)

Jaffri, A. A. (2001, June). Al Balagh.

Kason, Y. (2008). Farther shores: Exploring how near-death, kundalini and mystical experiences can transform ordinary lives. Bloomington, IN: iUniverse.

Moody, R. A. (1975). Life after life. Covington, GA: Mockingbird Books.

Morse, M. L., \& Perry, P. (1994). Parting visions: Uses and meanings of pre-death, psychic, and spiritual experiences. New York, NY: Villard.

Murphy, T. (2001). Near-death experiences in Thailand. Journal of Near-Death Studies, 19, 161-178.

Osis, K., \& Haraldsson, E. (1977). At the hour of death. New York, NY: Avon.

Pasricha, S. (1993). A systematic survey of near-death experiences in South India. Journal of Scientific Exploration, 7, 161-171.

Ring, K., \& Valarino, E. E. (1998). Lessons from the light: What we can learn from the near-death experience. New York, NY: Plenum/Insight.

Ritchie, G. G. (1991). Ordered to return: My life after dying. Charlottesville, VA: Hampton Roads.

Suleman, A. (2004). A passage to eternity. Calgary, Canada: Amethyst.

Usmani, T. (2009). Dunya ke us par [This world and the beyond]. Retrieved from http:// www.scribd.com/doc/20578922/Dunya-Ke-Us-Par-By-MUFTI-TAQI-USMANI

Zaleski, C. (1985). Evaluating near-death testimony: A challenge for theology. Anabiosis: The Journal for Near-Death Studies, 5(2), 17-52.

Zhi-ying, F., \& Jian-Xun, L. (1992). Near-death experiences among survivors of the 1976 Tangshan earthquake. Journal of Near-Death Studies, 11, 39-48.

Zingrone, N. L., \& Alvarado, C. S. (2009). Pleasurable Western adult near-death experiences: Features, circumstances, and incidence. In J. M. Holden, B. Greyson, \& D. James (Eds.), The handbook of near-death experiences: Thirty years of investigation. Santa Barbara, CA: Praeger/ABC-CLIO. 